\title{
TECHNIQUES OF ROCKFALL INVENTORY IN EARTHQUAKE PRONE ROCK SLOPES
}

\author{
Zygouri V. ${ }^{1}$ and Koukouvelas I. ${ }^{1}$ \\ ${ }^{1}$ University of Patras, Department of Geology, 26500, Rion Patras, Greece, zygouri@upatras.gr, \\ Koukouvelas@iannis.gr
}

\begin{abstract}
A relevant hazard in mountainous regions is the steep rock slopes concentrating rock falls. Although rock falls are characterized by smaller rock volumes compared to other landslide types, can also provoke severe damage to buildings, infrastructures and human life due to their sudden and highly fast movement. The key to understand the processes that result in rock fall onset is an integrated study of the major causing parameters that affect slope stability. A rock slope may be subjected to many forms of triggering factors including tectonic, geomorphic, seismic, climatic or even human induced damages. This contribution provides an overview of the previous and current research related to rock falls and uses case studies of North Peloponnese in order to prove the usefulness of these methods in the Greek territory. Collecting data and production of thematic maps by means of field and remote sensing investigations can yield far more updated results incorporated in hazard assessment techniques and protection measures.
\end{abstract}

Keywords: rock slope stability, triggering factors, rock fall hazard assessment.

\section{Пєрí $\eta \psi \eta$}

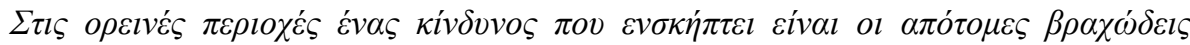

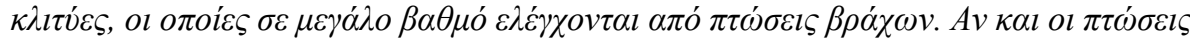

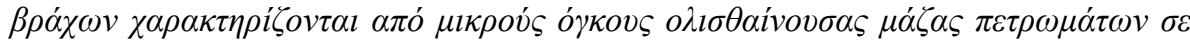

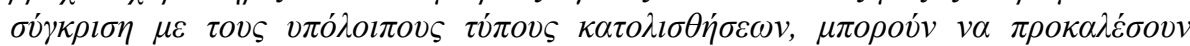

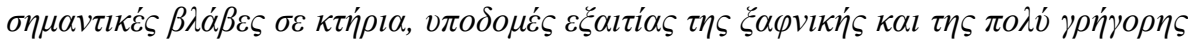

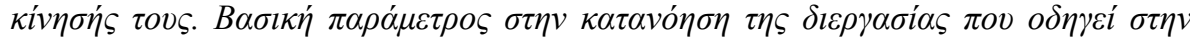

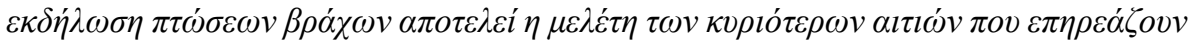

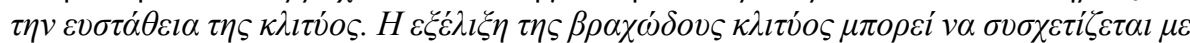

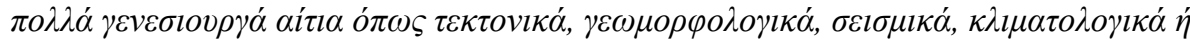

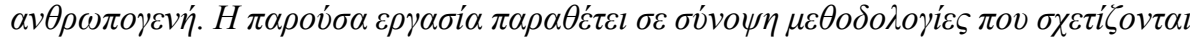

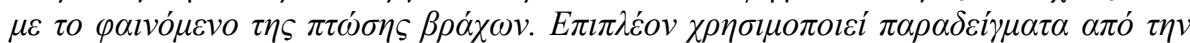

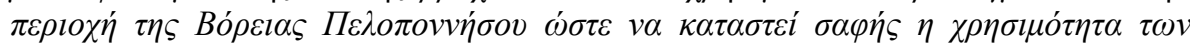

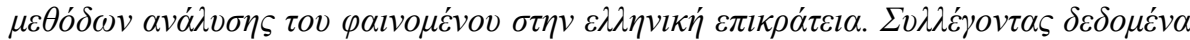

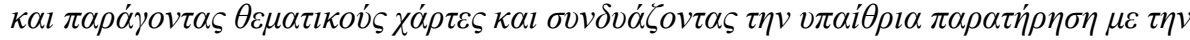

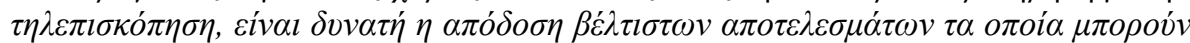

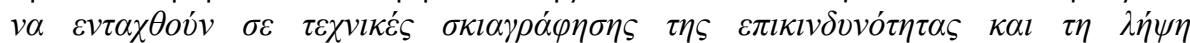

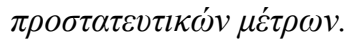

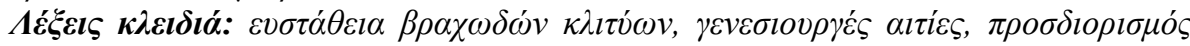

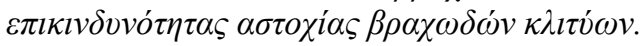




\section{Introduction}

Landslides are located on a variety of lithological and geological domains throughout the world. They encompass a variety of failure types, can be very slow to very fast moving, and pose different hazards and risk. Their impacts on structures, human activity and loss of life can be substantial, ranging from slow deformation of buildings and roads, to sudden damage of developed areas. Geological evolution (Ballantyne, 2002), lithology and structure (Ambrosi and Crosta, 2006), slope relief and shape (Molnar, 2004), weather and climate (Ballantyne, 2002), seismicity (Keefer, 1984; Crosta et al., 2005) and human activity (Cruden, 1976) are the most important causative factors of slope stability in general (Fig. 1). Geomorphology, structural and engineering geology enable the specification of the main characteristics of a slope in distinct ways that can be combined to provide a complementary view of the operative slope processes.

Slope tectonics as an earth science discipline focuses on gravity - driven mass wasting processes caused by unique rock and soil fabrics, internal and external structures of the moving landmasses and topographic features. Although the studies of deformation features related to slope failure have been century old, integrated approaches employing methods from engineering geology, structural geology, geodesy and geomorphology emerged only recently as the scientific community introduced the digital ages. A key issue in the studies of slope tectonics is to distinguish the features related to active tectonics (driven primarily by tectonic forcing) to features that were purely generated by gravity and climatic conditions and its induced rock failure on topographic slopes.

Aim of this paper is to present and discuss the inventory of distribution of slope instabilities in the north Peloponnese area with respect to some of the most important geological and geomorphological features and variables. Note that this area is prone either to tectonic (Koukouvelas et al., 1996, 2015) or meteorological forcing (Lainas et al., 2015). This will give the chance to discuss the most important features associated with these phenomena and their criteria for their recognition and to provide a broad, even though not complete, overview of the predisposing and controlling factors, as well as the relationships of sliding distribution with the main landscape topographic characteristics. In addition, we will evaluate the actual impact of such phenomena at a regional scale correlated with field evidence and the various suggested models from the world experience. Especially, in the Greek literature only few inventories have been presented (i.e. Antoniou and Lekkas, 2010; Papathanassiou et al., 2013; Sabatakakis et al., 2013; Koukouvelas et al., 2015; Lainas et al., 2015; Saroglou et al., 2015). Finally, we will test the applicability of rock fall models in two Greek case studies where climatic and tectonic forcing is acting at constantly developed and populated areas of the Northern Peloponnese.

\section{Rock fall process}

Rockfall is a slope process in which a rock mass detaches from a steep face of a rock cliff and descends extremely fast by falling and subsequently rolling, sliding or bouncing and finally stopping (Varnes, 1978). Commonly rockfalls are concentrated where screes are developed. Rockfall activity depends primarily on geological, tectonic and topographical factors but commonly these processes are sensitive to the meteorological conditions (Fig. 1). Rockfalls are common in mountain areas and represent a serious threat due to their high propagation velocity that, independently from the volume involved, can be extremely dangerous to buildings, roads and people. Therefore, it is necessary to preliminarily identify those areas, most vulnerable to this type of process, in order to pursue a territorial planning with consciousness of hazards and risks. Rockfall hazard analysis over wide territories is rather difficult, because many variables, which are difficult to identify at that scale, have to be taken into account (i.e., rock fracturing, water presence etc.). Hence, there is a need for identifying methodologies capable of reproducing complex processes involved in rockfall occurrence and propagation and to preliminarily identify the areas prone to this type of hazard. Methodological contributions contain rockfall susceptibility together with hazard assessment and zoning, rockfall initiation and runout modeling, design and performance evaluation of rockfall 
protection systems such as fences, ditches or forests (Piacentini and Soldati, 2008). Although rockfalls involve smaller rock volumes compared to other landslide types (e.g. deep gravitational slides), rock fall events also cause severe damage to buildings, infrastructures and lifelines due to their unexpected frequency, their easily release and high kinetic energy (Rochet, 1987).

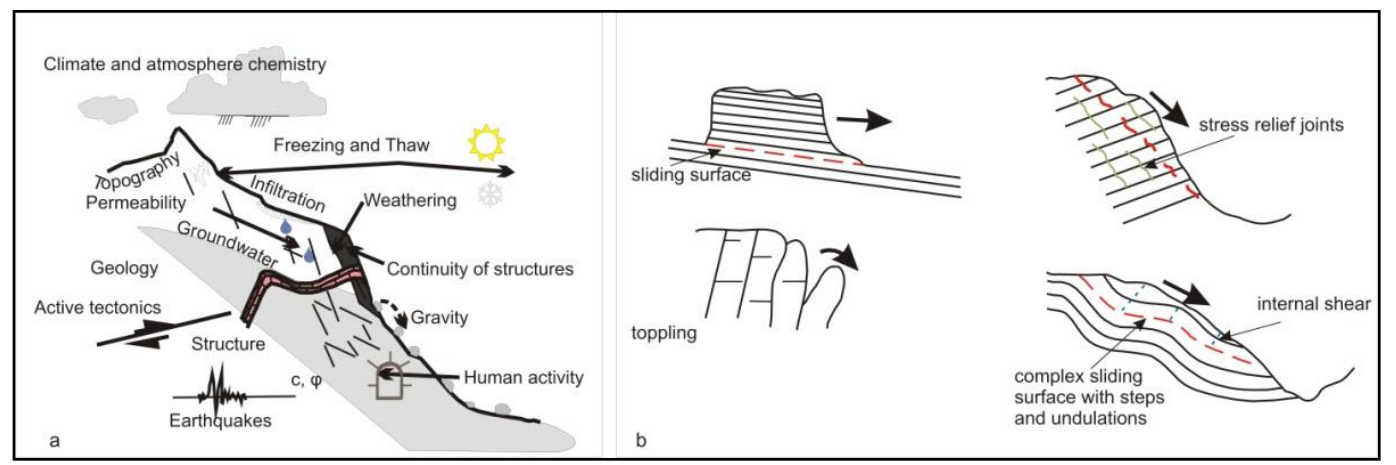

Figure 1 - a) Basic parameters influence slope stability (modified after Volkwein et al., 2011). b) Slope failures related to geological structures (modified after Clastonburry and Fell, 2000; Stead and Wolter, 2015).

To highlight that local geology is one of the major factors for slope instabilities, the individual characteristics of two selected sites are presented, the Skolis Mt and the Acrocorinthos study-sites. These localities can represent a prominent risk for inhabitants and infrastructure and have therefore been the subject for field analyses (Koukouvelas et al., 2015; Zygouri and Koukouvelas, 2015). Both areas are controlled by large scale tectonic features and have experienced strong earthquake shaking and consist of similar lithological units.

\section{Material and Methods}

Classification of slope mass movements is mainly based on materials and types of mechanism. The study of slope instabilities requires a complete collection, organization and interpretation of historical, geomorphological and geological data, both from field and remote sensing surveys. There have always been two different kinds of approach in the study of slope instabilities: the geomorphological and the structural prospect (Fig. 1). By the integration of these two kinds of approach it is possible to describe their geometry and their controlling factors in order to evaluate susceptibility of rock slope instabilities and estimate the hazard originated from such phenomena. A detailed characterization and interpretation of slope instability phenomena is possible through analysis and synthesis of a complete series of field data integrated with remote sensing information. The comparison of different data sources (archival searches, eye - witness accounts and aerial or satellite photo interpretation) allows enriching the cartographic database and precisely confining a certain instability phenomenon verified in the past (Giardino et al., 2004).

\subsection{Rockfall release areas}

Various techniques have been implemented on rock slopes to characterize and examine them, ranging from field surveys to remote sensing. Traditional rock slope investigations often initiate with field observations of the rock mass, including intact rock descriptions and discontinuity measurements and characterization. The simplest way to detect a source area is to use the slope angle threshold (Guzzetti et al., 2003) or to add some other criteria as the presence of cliff areas, lithology conditions, i.e. lithology alternations, and tectonics (Jaboyedoff and Labiouse, 2003). We emphasize also the importance of tectonic damage on rock masses (i.e. Marinos and Hoek, 2002). This damage reduces the strength of rock masses and also provides the kinematics required for slope displacements (Fig.1b). Hence, the factors affecting a rock fall area are summarized by Jaboyedoff and Derron (2005): 
- Morphology: slope angle, height of slope, exposure

- Geology: rock types and weathering, variability of the geological structure, bedding, type of deposits

- Fracturing: joint sets and their trace lengths, etc.

Depending on the material, the morphology and the presence of weakness zones or other external factors the scale of rock falls can vary from small to large sections of slope to entire mountain flanks and ridges (i.e. Crosta et al., 2006).

\subsection{Rockfall trajectories - Empirical statistical models}

Rock mass commonly breaks up when impacting on the ground during its descent. This breaking produces individual rock blocks, or fragmental blocks, which can move independently when the size of the detached rock mass is roughly less than $10^{5} \mathrm{~m}^{3}$ (Evans and Hungr, 1993). It is important, for practical purposes, to delineate the movement of a falling rock along a slope called its trajectory (Fig. 2). The trajectories of falling rocks can be described as an approximation of four types of motion free fall, rolling, sliding and bouncing of a falling block (Descoeudres, 1997). The distance that the fallen rocks cross, is referring as travel distance. The estimate of this distance is considered as important in terms of hazard analysis and is based either on field/empirical statistical or dynamic techniques (Okura et al., 2000; Legros, 2002; Corominas et al., 2005; Ruiz et al., 2015). The type of model to be applied for estimating travel distance, is chosen according to the mapping scale of the area and the purposes of the results. Empirical models suggest an easy way to assess and predict travel distances of fallen rocks. There are two basic empirical models widely implemented: the reach angle and the shadow angle.

\subsubsection{Reach angle}

The reach angle evaluation introduces the definition of the release point of a rock fall as it is described above. The concept of the reach angle is based on an energy line applied from the rock fall source point dipping downslope along its trajectory path (Fig. 2). The fallen rock will stop either when it loses its kinetic energy or when blocked on a barrier (e.g. a tree cluster), so the path constrains its downward course (Heim, 1932; Corominas, 1996; Jaboyedoff and Labiouse, 2003; Copons et al., 2009). The reach angle calculated by the H/L ratio (Fig. 2) is equivalent to the Fährböschung angle (Heim, 1932; Scheidegger, 1973), and travel angle (Cruden and Varnes, 1996) with the term reach angle being the most popular.

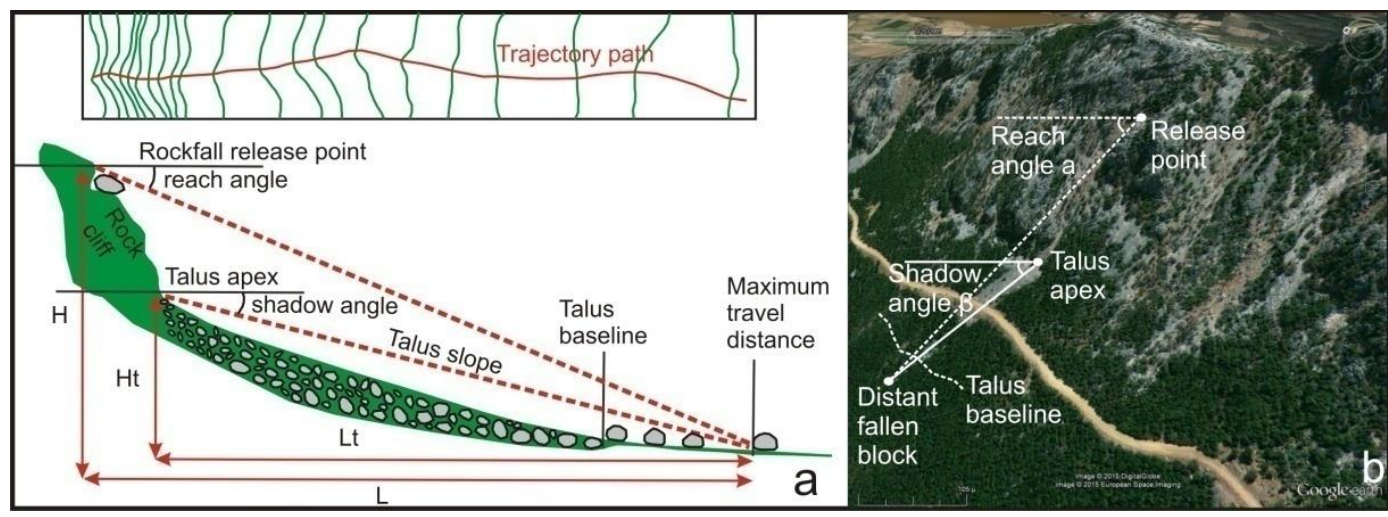

Figure 2 - a) Simplified sketch showing the required calculated parameters for the determination of reach and shadow angle (modified by Copons et al., 2009). b) Example of the determination of both angles in a satellite image. 


\subsubsection{Shadow angle}

The shadow angle method defines the talus apex as the point that a fallen block can either travel down slope or can attain a stability mode by accumulating talus scree. Evans and Hungr (1993) proposed that the kinetic energy that rock blocks attain during their fall along the steep slope is significantly diminished immediately after the first impact on the ground. Thus, the travel distance of the fallen block after the ground impact does not depend on the height of the rock fall release point but incorporates the point that the farthest fallen blocks stop which shape the minimum shadow angle envelope. This angle is determined as a common geometrical problem where the arctangent of angle $\beta$ is calculated (Fig. 2). It is also independent of time since it does not require the study of a single rockfall incident but the maximum point that a block can reach whenever and whatever way it occurred.

\section{Application of methods in North Peloponnese}

We selected two case studies in order to apply these two models that comprise a common toolbox in literature about rockfall phenomena. The area of North Peloponnese is significant for this kind of study. It combines weather conditions that favour flash floods and is dominated by steep slopes due to the presence of impressive carbonate fault controlled escarpments. Therefore, it highlights strong seismicity both onshore and offshore but on the other hand is constantly developed and populated. Thus, it favours the instability phenomena and its growing development assigns them as risk factors for its unhindered course. We chose the areas of Skolis Mt and Acrocorinthos in order to study slope instabilities. The first area has suffered a strong earthquake over the last decade that make known the problem that the west flank of Skolis Mt. is a rockfall terrain. The second area is an area of recognised cultural value that suffers from time to time strong earthquakes and from slope instability incidents as well.

\subsection{Rockfall release areas}

Heim (1932) suggested that the required treaty for rock fall initiation is the slope steepness. Apart from topography, Keefer (1984) charged moderate to strong earthquakes as responsible triggering factors for slope failures. Both studied areas present rock fall distribution related to faulting and induced seismicity. The steepness of the Skolis Mt. slope reaches up to $70^{\circ}$, whereas the Acrocorinthos cliff's slope is almost $50^{\circ}$. The lithology of the rockfall source areas for both case studies is fractured Mesozoic carbonate rocks, whereas the orientation of analogue and digital air photos revealed that the rockfall source area elevation range from $450 \mathrm{~m}$ 七o $970 \mathrm{~m}$ for the Skolis Mt and from $350 \mathrm{~m}$ to $500 \mathrm{~m}$ for the Acrocorinthos and that both slopes are located within a $300 \mathrm{~m}$ buffer as Wagner et al. (1990) suggest for fault influence on slopes (Fig. 3). Structural surveys highlight at least three major sets of discontinuities for both areas including bedding planes. They form wedges whose axis dip down to the slope (Fig. 4). Thus, the geometry of the slope is favourable for slope failures. Especially the height and angle of slopes, the presence of convexity on its surface may be responsible for topographic site effects (Athanasopoulos et al., 1999; Bouckovalas and Papadimitriou, 2005). The progressive role of discontinuities has a major impact on the stiffness of the rock mass and can become potential sliding planes for the detachable blocks but is not enough for the initiation of a rockfall (Baillifard et al., 2003; Stead and Wolter, 2015; Mavrouli and Corominas, 2015).
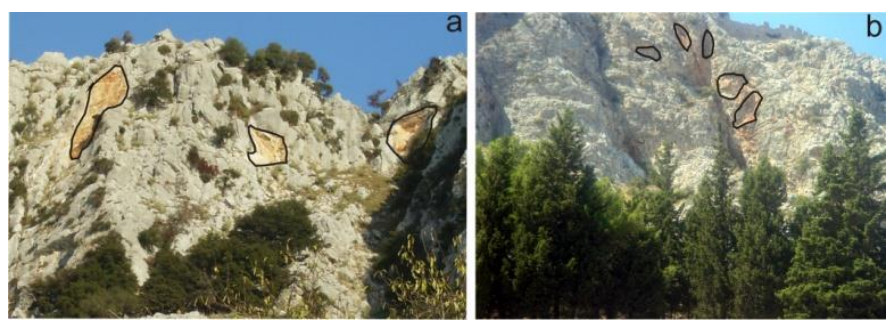

Figure 3 - Rock fall release areas in a) Skolis and b) Acrocorinthos steep rock slopes. 

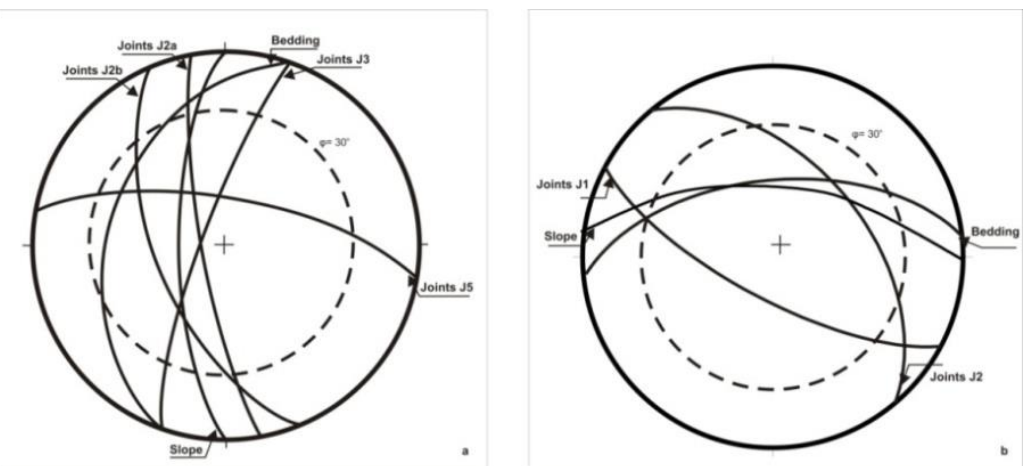

Figure 4 - Kinematic slope stability analysis accounting for planar and wedge sliding for a) Skolis Mt and b) Acrocorinthos.

\subsection{Rockfall trajectories}

The scree slope that is forming beneath the carbonate slope is the place where all fallen blocks are concentrated on a resting point. This means that they lose their kinetic energy that has been already partially lost since their contact to the ground. During their travel, fallen rock blocks can either break down into smaller fragments or bounce on the steep slopes and roll over the scree slope (Fig. 5a). During the 2008 earthquake eyewitnesses declared that large blocks of rock with volumes ranging from 3 to $20 \mathrm{~m}^{3}$, rolled and toppled down at the Santomerion community boundaries with a couple of them entering into village (Fig. 5b). In Acrocorinthos as well, rock volumes less than $100 \mathrm{~m}^{3}$ are spread out across the scree of moderately to gently inclined slope (Fig. 5c). Several seismic events such as the 1858, the 1924 and the 1981 events probably motivated the rockfall initiation. Isolated boulders and their correlated rockfall source areas recognized in air photo archives and satellite images were used in order to estimate reach and shadow angle values. Comparing our values with the values calculated in other areas of the Mediterranean area our case studies resembles similar slope behaviors (Fig. 6a, b).
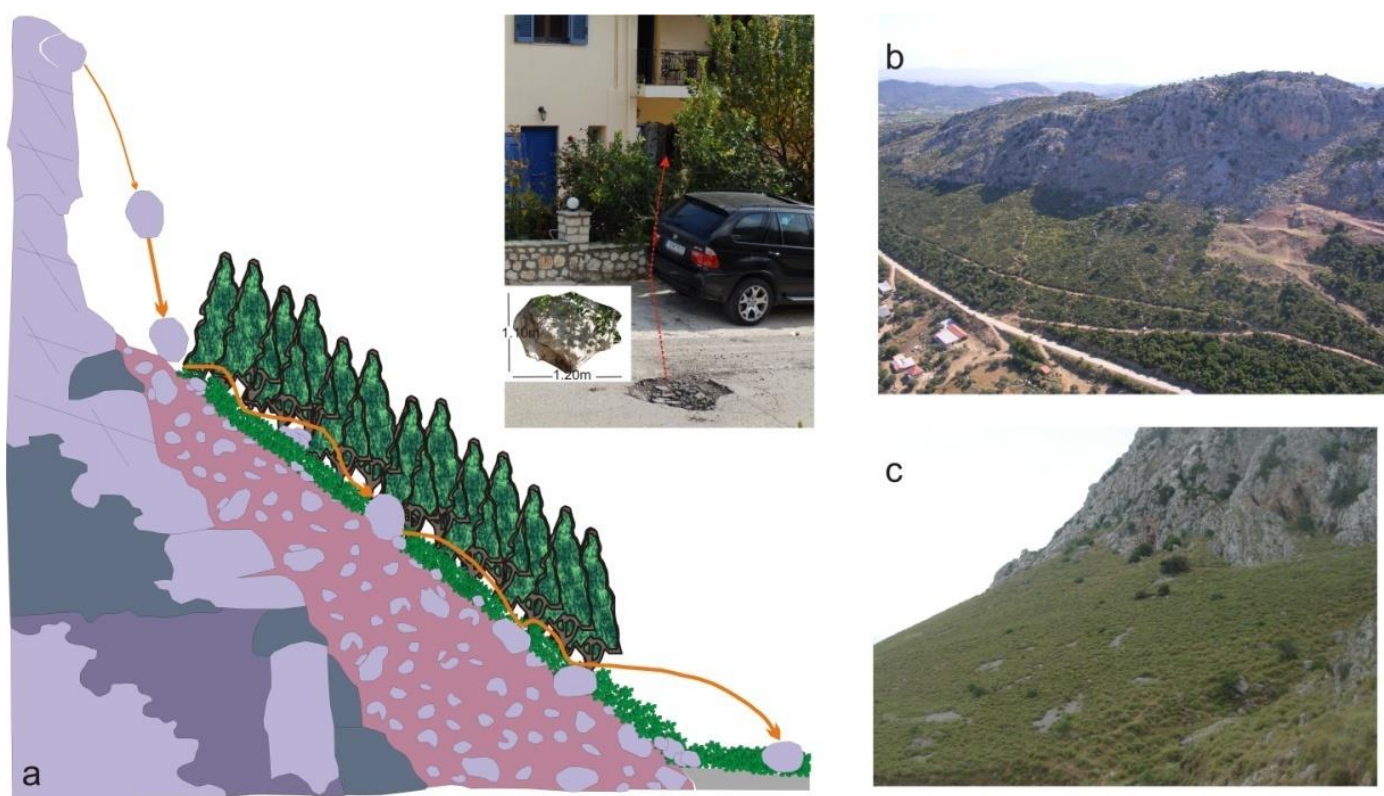

Figure 5 - a) Schematic representation of the travel of a fallen rock block. The inset figure shows an example of an isolated boulder bouncing in the recent Lefkas earthquake (November 2015). b, c) Propagation of fallen rock block terrains in Skolis Mt and Acrocorinthos. 


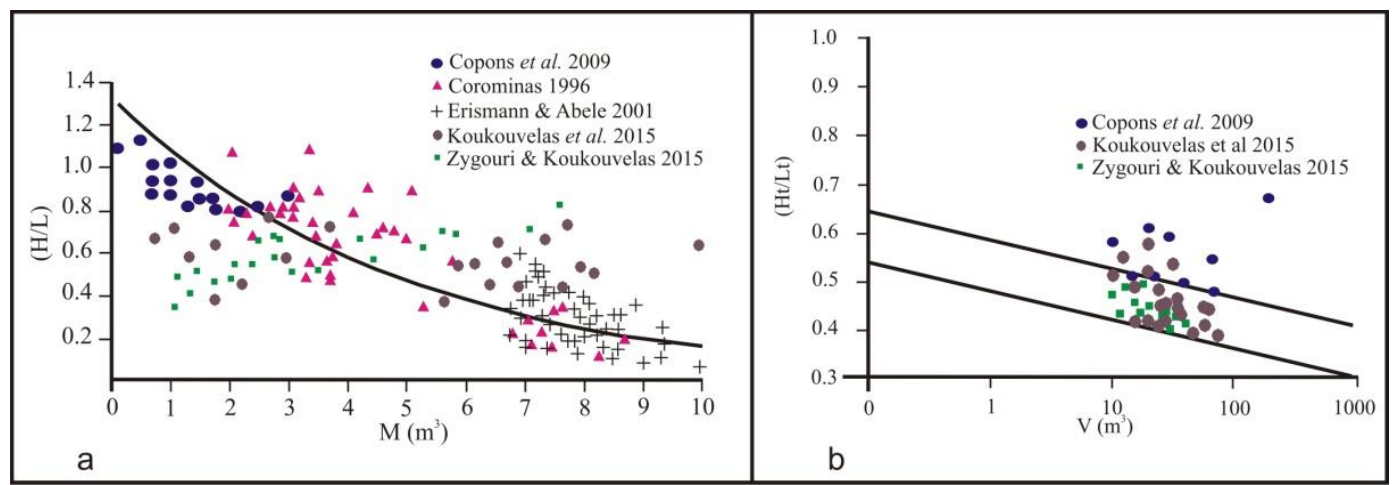

Figure 6 - Plots of Mediterranean rock fall sites parameters. a) Plot of rock fall size vs. tangent of the reach angle. b) Plot of rock fall volume vs. tangent of the shadow angle.

Our work revealed that the uniformitarianism, the guiding principle of geology, suggest that the same geologic and geomorphic situations that led to past and present instabilities will be responsible for future slope instabilities. Therefore, the minimum shadow angle of $24^{\circ}$ consists a threshold value that captures the farthest travelled boulder and highlights the zone of potential rock fall hazard for both the Skolis Mt and the Acrocorinthos area (Fig. 7).

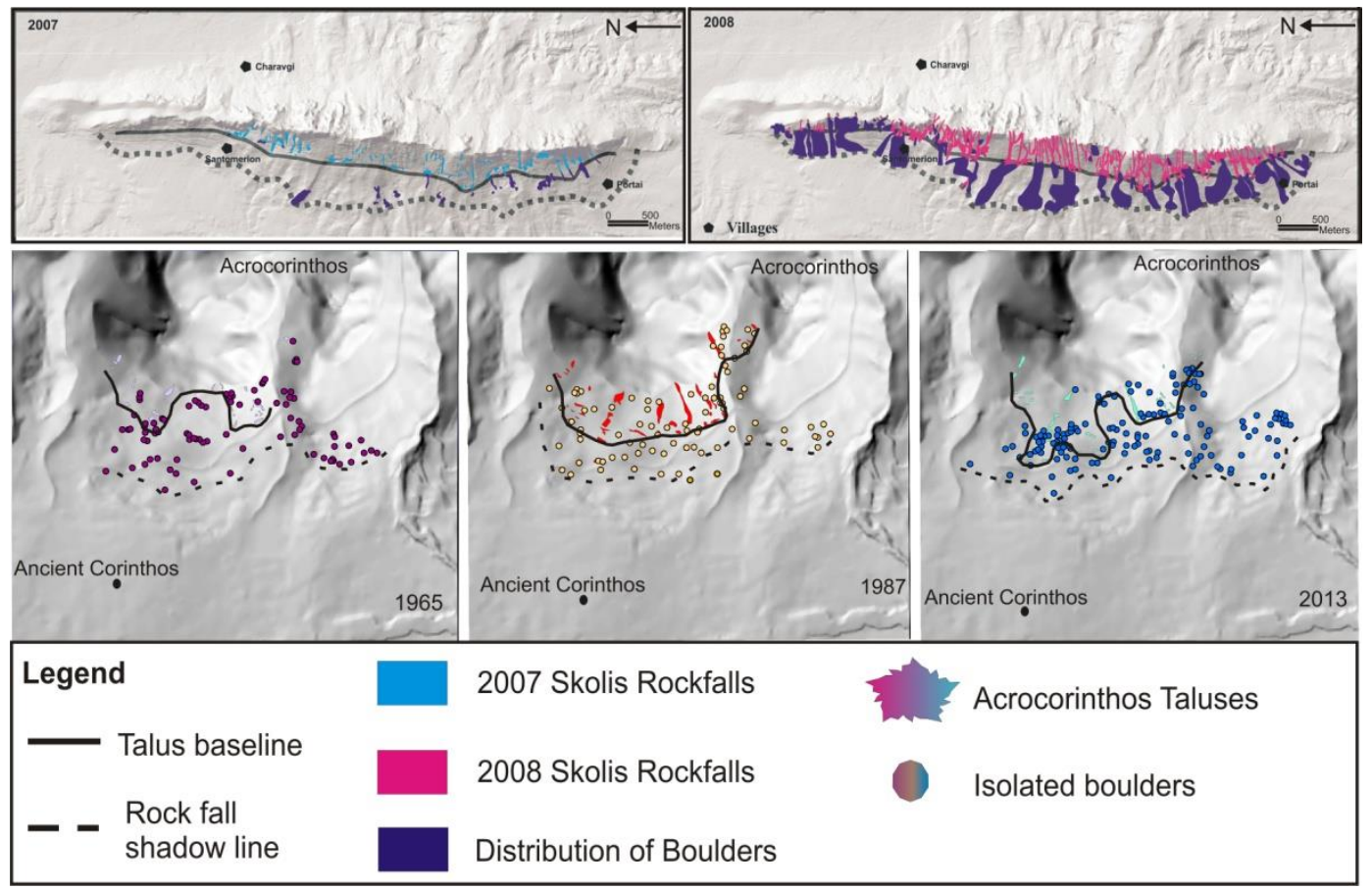

Figure 7 - Shaded relief maps showing the evolution of rock fall sites in different dates for Skolis Mt (upper figures) and Acrocorinthos (bottom figures).

\section{Discussion and conclusive remarks}

It is obvious that hazard caused by boulders that spread beyond the talus deposit can be calculated. The calculated values can be implemented in GIS platforms. These platforms can become a valuable tool in order to estimate the hazard outlined by rockfalls in a given area. The vulnerability of people to rockfalls and to any natural hazard is identified by the relationship between the occurrences of 
extreme events, the proximity of houses or life lines to these occurrences and the degree of public awareness and state of preparedness. The concept of the hazard as the intersection of the human system and the natural process, in our case the slope instability phenomena, is illustrated in fig. 8. The required condition to establish a hazard for public safety is the interaction between the above mentioned systems. The analysis by using aerial photography and satellite images comprises a quick and valuable technique, because it provides a three -dimensional overview both of the studied terrain and the human activities on it. In addition, the application of shadow angle does not require correlation of the release points with particular isolated boulders, but needs the identification of the farthest boulders that have fallen in the recent past. Today's rockfall hazard issues and estimation of the risk of rock fall are considered essential. Recent earthquakes in Alkyonides islands (Marinos et al., 1986), Parnitha Mt (Pavlides et al., 2002), Movri Mt (Koukouvelas et al., 2010, 2015), Lefkada (Papathanassiou et al., 2013) and Cephalonia island (Papadopoulos et al., 2014) showed that Greek type earthquakes are usually accompanied by small to large scale slope instabilities, including commonly rockfalls. Taken together the recent impacts of ground shaking in Greece and the preliminary results from two areas of high seismic risk we identify that the method used can give reliable results. Our analysis indicates that the rockfall hazard over the north Peloponnese is almost homogenous in term of their geology, steepness of slope, and climatic and tectonic forcing. Especially, the evolution of the studied rockfall terrains shows that the seismic impact prevail the climatic impact in areas encountered tectonic forcing. Considering that more than $12 \%$ of the instability phenomena recorded in Greece is earthquake induced (Koukis et al., 2015) and their mitigation is cost and time consuming the need for objective and accurate tools is absolutely necessary. These results can better quantify the risk of rockfall and improve hazard and risk maps. However, it is becoming increasingly important that researchers from different disciplines should establish close collaboration in order to efficiently provide a supplementary view of the operative slope processes, since geomorphology, structural geology and engineering geology can provide different aspects in the examination of a rock slope process.

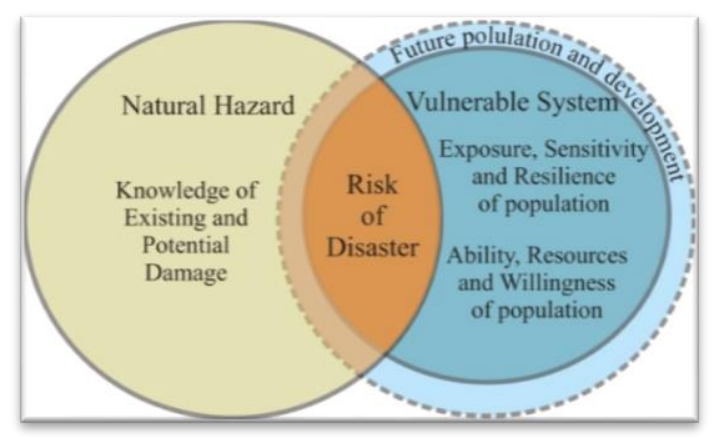

Figure 8 - The impact of natural hazard on a vulnerable system as the human polulation.

\section{Acknowledgments}

This work was supported by Grant E078 to V. Zygouri and I. Koukouvelas from the Research Committee of the University of Patras (Programme K. Karatheodori).

\section{References}

Ambrosi, C. and Crosta, G.B., 2006. Large sacking along major tectonic features in the Central Italian Alps, Engineering Geology, 83,183-200.

Antoniou, A.A. and Lekkas, E., 2010. Rockfall susceptibility map for Athinios port, Santorini island, Greece, Geomorphology, 118, 152-166. 
Athanasopoulos, G.A., Pelekis, P.C. and Leonidou, E.A., 1999. Effects of surface topography on seismic ground response in the Egion (Greece) 15 June 1995 earthquake, Soil Dynamics and Earthquake Engineering, 18, 135-149.

Baillifard, F., Jaboyedoff, M. and Sartori, M., 2003. Rockfall hazard mapping along a mountainous road in Switzerland using a GIS-based parameter rating approach, Natural Hazards and Earth System Sciences, 3, 435-442.

Ballantyne, C.K., 2002. Paraglacial geomorphology, Quarterly Science Review, 21, 1935-2017.

Bouckovalas, G.D. and Papadimitriou, A.G., 2005. Numerical evaluation of slope topography effects on seismic ground motion, Soil Dynamics and Earthquake Engineering, 25, 547-558.

Copons, R., Vilaplana, J.M. and Linares, R., 2009. Rockfall travel distance analysis by using empirical models (Solà d' Andorra la Vella, Central Pyrenees), Natural Hazards and Earth System Sciences, 9, 2107-2118.

Corominas, J., 1996. The angle of reach as a mobility index for small and large landslides, Canadian Geotechnical Journal, 33, 260-271.

Corominas, J., Copons, R., Moya, J., Vilaplana, J.M., Altimir, J. and Amigó, J., 2005. Quantitative assessment of the residual risk in a rockfall protected area, Landslides, 2, 343-357.

Crosta, G.B., Imposimato, S., Roddeman, D., Chiesa, S. and Moia, F., 2005. Small fast-moving flow-like landslides in volcanic deposits: The 2001 Las Colinas Landslide (El Salvador), Engineering Geology, 79, 185-214.

Crosta, G.B., Chen, H. and Frattini, P., 2006. Forecasting hazard scenarios and implications for the evaluation of countermeasure efficiency for large debris avalanches, Engineering Geology, 83, 236-253

Cruden, D.M., 1976. Major rock slide in the Rockies, Canadian Geotechnical Journal, 13, 8-20.

Cruden, D.M. and Varnes, D.J., 1996. Landslide types and processes. In: Tucker, A.K. and Shuster, R.L., eds., Landslides: investigation and Mitigation, Special Report 247, Transportation Research Board, National Reseach Council, Washington D.C., 36-75.

Descoeudres, F., 1997. Aspects géomécaniques des instabilities de falaises rocheuses et des chutes de blocs, Publications de la société Suisse de mécanique des sols et des roches, 135, 3-11.

Erismann, T. and Abele, G., 2001. Dynamics of Rockslides and Rockfalls, Springer, Berlin, 316.

Evans, S.G. and Hungr, O., 1993. The assessment of rockfall hazard at the base of talus slopes, Canadian Geotechnical Journal, 30, 620-636.

Giardino, M., Giordan, D. and Ambrosio, S., 2004. G.I.S. technologies for data collection, management and visualization of large slope instabilities: two applications in the Western Italian Alps, Natural Hazards and Earth System Sciences, 4, 197-211.

Guzzetti, F., Reichenback, P. and Wieczorek, G.F., 2003. Rockfall hazard and risk assessment in the Yosemite Valley, California, USA, Natural Hazards and Earth System Sciences, 3, 491-503.

Heim, A., 1932. Bergsturz und Menschenleben. Beiblatt Vierteljahrschrift Naturforsch, Gesell, Zürich, 77.

Jaboyedoff, M. and Labiouse, V., 2003. Preliminary assessment of rockfall hazard based on GIS data, $10^{\text {th }}$ International Congress on Rock Mechanics ISRM 2003 - Technology roadmap for rock mechanics, Johannesburgh, South Africa, 575-578.

Jaboyedoff, M. and Derron, M.-H., 2005. Integrated risk assessment process for landslides. In: Hungr, O., Fell, R., Couture, R.R. and Eberhardt, E., eds., Landslide risk management, 776.

Keefer, D.K., 1984. Landslides caused by earthquakes, Geological Society of America Bulletin, 95, 406-421.

Koukis, G., Pyrgiotis, L. and Kouki, A., 2015. Landslide phenomena in Greece: Types of movement related to the lithology and structure of the geological formations, In: Lollino, G., Giordan, D., Crosta, G., Coominas, J., Azzam, R., Wasowski, J. and Sciarra, N., eds., Engineering Geology for Society and Territory, 2, 1023-1027.

Koukouvelas, I., Mpresiakas, A., Sokos, E. and Doutsos, T., 1996. The tectonic setting and earthquake ground hazards of the 1993 Pyrgos earthquake, Peloponnese, Greece, Journal of the Geological Society, 153, 39-49.

Koukouvelas, I., Litoseliti, A., Nikolakopoulos, K. and Zygouri, V., 2015. Earthquake triggered rock falls and their role in the development of a rock slope: The case of Skolis Mountain, Greece, Engineering Geology, 191, 71-85. 
Lainas, S., Sabatakakis, N. and Koukis, G., 2015. Rainfall thresholds for possible landslide initiation in wildfire - affected areas of western Greece, Bulletin of Engineering Geology and the Environment, 1-14.

Legros, F., 2002. The mobility of long - runout landslides, Engineering Geology, 63, 301-331.

Mavrouli, O. and Corominas, J., 2015. Comparing kinematically detachable rock masses and rockfall scar volumes, IOP Conference series: Earth and Environmental, 26, 012020, Warwick UK, 10-11 September, doi:10.1088/1755-1315/26/1/012020.

Marinos, P.G., Koukis, G., Stournaras, G. and Skias, S., 1986. Landslide phenomena triggered by the 1981 Alkyonides earthquakes. Relation with active faults and urban planning if the area, KEDE Bulletin, 3-4, 106.

Molnar, P., 2004. Interactions among topographically induced elastic stress, static fatigue and valley incision, Journal of Geophysical research, 109, F02010, doi: 10.1029/2003JF000097(09).

Okura, Y., Kitahara, H., Sammori, T. and Kawanami, A., 2000. The effects of rockfall volume on runout distance, Enineering Geology, 58, 109-124.

Papadopoulos, G.A., Karastathis, V., Koukouvelas, I.K., Sachpazi, M., Baskoutas, I., Chouliaras, G., Agalos, A., Daskalaki, E., Minadakis, G., Moshou, A., Mouzakiotis, A., Orfanogiannaki, K., Papageorgiou, A., Spanos, D. and Triantafyllou, I., 2014. The Cephalonia, Ionian Sea (Greece), sequence of strong earthquakes of January - February 2014: a first report, Research in Geophysics 2014, doi:10.4081/rg.2014.5441.

Papathanassiou, G., Valkaniotis, S., Ganas, A. and Pavlides, S., 2013. GIS-based statistical analysis of the spatial distribution of earthquake - induced landslides in the island of Lefkada, Ionian Islands, Greece, Landslides, 10, 771-783.

Pavlides, S.B., Papadopoulos, G. and Ganas, A., 2002. The fault that caused the Athens September 1999 Ms=5.9 earthquake: Field observations, Natural Hazards, 27, 61-84.

Piacentini, D. and Soldati, M., 2008. Application of empiric models for the analysis of rock-fall runout at a regional scale in mountain areas: Examples from the dolomites and the northern Apennines (Italy), Geografia Fisica e Dinamica Quaternaria, 31, 215-223.

Rochet, L., 1987. Application des modèles numeriques de propagation à l'étude des éboulements rocheux, Bulletin de liaison des laboratories des ponts et chausses, 150-151, 84-95.

Ruiz, R., Corominas, J. and Mavrouli, O., 2015. Comparison of block size distribution in rockfalls, Proc. $24^{\text {th }}$ European Young Geotechnical Engineers Conference (EYGEC), Durham, UK.

Sabatakis, N., Koukis, G., Vassiliades, E. and Lainas, S., 2013. Landslide susceptibility zonation in Greece, Natural Hazards, 65, 523-543.

Saroglou, H., Berger, F., Bourrier, F., Asteriou, P., Tsiambaos, G. and Tsagkas, D., 2015. Effect of forest presence on Rockfall Trajectory. An example from Greece, In: Lollino G., Giordan, D., Crosta, G., Coominas, J., Azzam R., Wasowski, J. and Sciarra N., eds., Engineering Geology for Society and Territory, 2, 1899-1903.

Scheidegger, A.E., 1973. On the prediction of the reach and velocity of catastrophic landslides, Rock Mechanics, 5, 231-236.

Stead, D. and Wolter, A., 2015. A critical review of rock slope failure mechanisms: The importance of structural geology, Journal of Structural Geology, 74, 1-23.

Varnes, D.J., 1978. Slope movement types and processes. In: Scuster, R.L. and Krizek, R.J., eds., Landslides, Analysis and Control - Special Report 176. National Academy of Sciences, Washington DC, 11-33.

Wagner, A., Leite, E. and Olivier, R., 1990. SHIVA, a landslide hazard mapping software, Vol. 1: Users guide, Vol.2: Annexes and case studies, Inst. Géoph Université de Lausanne and ITECO, Affoltern a.A.

Zygouri, V. and Koukouvelas, I.K., 2015. Evolution of rock falls in the Northern part of the Peloponnese, Greece, IOP, Conference series: Earth and Environmental, 26, 012043, Warwick UK, 10-11 September, doi:10.1088/1755-1315/26/1/012043. 